\title{
Adapting Macbeth in a Lusophone context: The challenges of intercultural performance
}

\author{
Francesca Rayner \\ CEHUM, Universidade do Minho, Portugal
}

\begin{abstract}
This article analyses the intercultural performance of The Prayers of Mansata, an adaptation of Shakespeare's Macbeth to the West African context of Guinea-Bissau. After a critical exploration of contemporary intercultural theory, it charts the relationship between the Shakespearean text and this adaptation, before exploring particular questions raised by the circulation of the performance within different Portuguese-speaking contexts. It argues that such performances can represent a potent social and political intervention in contemporary configurations of power within a Portuguese-speaking community of nations by combining concerns with local specificity and wider concerns with a post-colonial present.
\end{abstract}

KEYWORDS: Shakespeare; Macbeth; postcolonial; Lusophone; adaptation; performance.

\section{Introduction}

Between 2012 and 2013, the Portuguese theatre association, Cena Lusófona, organized a series of training workshops for performers and technicians in the former Portuguese colonies of Angola, Guinea-Bissau and São Tomé and Príncipe. ${ }^{1}$ Several participants from these workshops were then chosen to work with performers

\footnotetext{
${ }^{1}$ For more details of the project, in Portuguese and English see the Cena Lusófona blog at http://pstage.wordpress.com. The author observed the workshops and performances in Bissau in 2013 and 2014 and also saw the performances in Coimbra, Portugal in 2014.
} 
from Portugal and Brazil on the staging of Abdulai Sila's As Orações de Mansata (The Prayers of Mansata), an adaptation of Macbeth to the West African context of Guinea-Bissau. After well-received performances in Portugal and Spain, thirteen actors and actresses from seven different Portuguese-speaking countries travelled to Bissau in May 2014. The performances played to large, responsive audiences who in turn encouraged heightened performances from the actors and actresses. Immediately afterwards, the production left for the final performances in Luanda, Angola. However, three hours before the actors and actresses were due on stage, the Angolan Minister of Culture banned the performances, ostensibly because the building in which they were due to perform was considered unsafe. Unable to convince the authorities to change their minds, the company was forced to cut short their tour and the performers returned to their respective countries. Although the event was mentioned in several newspapers, there was no coordinated response from political authorities or practitioners in any of these countries to this clear violation of freedom of speech in Angola.

The highs and lows of this intercultural production illustrate effectively some of the pleasures and paradoxes of discussing intercultural performances of Shakespeare in a post-colonial context. On the one hand, while Guinea-Bissau and Angola are both former Portuguese colonies, this common history does not explain the very different political reactions of the authorities. Why should the same performance be considered a significant cultural event in one national context and a political threat in another? ${ }^{2}$ Secondly,

\footnotetext{
${ }^{2}$ There was much comment within the Angolan media and especially in online social media on the cancellation of the performance. Government-friendly media emphasized the poor conditions of the space while anti-government media spoke of censorship. The opposition Bloco Democrático released a press statement on its blog (23 May, 2014) which affirmed that "The Angolan regime does not want to see itself questioned directly or indirectly, whether through politics or art, regarding the foundations of its regime, a regime that is corrupt and based on absolute power" while the Diário de Angola (19 May, 2014) ran the headline "Ministry of Culture censors play which portrays corruption." In another online article in Folha 8, (24 May, 2014) entitled "Censored culture or Nepotism" the journalist quotes the academic Eugénio Costa Almeida, who "does not believe that our Minister of Culture is one of those people who believe that culture is a dangerous means of exalting the intelligence and wisdom of the people, otherwise that would be censorship." In an article by Rita Siza in the Portuguese newspaper O Público (17 May, 2014), a heading focusing on the cancellation also included the ambivalent sub-heading "The decision is seen as equivalent to censorship because of the political nature of the performance.
} 
questions of Shakespearean status and authority are inflected differently in the two locations. While the combination of Abdulai Sila and Shakespeare worked jointly to enhance the status of both in Guinea-Bissau, Sila's text and the sign of Shakespeare worked against each other in Angola, as the Minister of Culture was clearly expecting a "safe" Shakespeare that would not encourage the kind of controversy that Sila's adaptation was designed to promote. To complicate matters further, it was precisely this "safe" Shakespeare that characterized earlier performances of the play in Portugal and Spain, where reasonable but less enthusiastic audiences read into the performances little of the subversive potential of Sila's play. The fact that no one spoke out against events in Angola within what is increasingly affirmed to be a Lusophone (Portuguese-speaking) community of nations problematizes these already politicized performances. ${ }^{3}$ Why was the trauma of non-performance in Angola met with an inability to create a coordinated Lusophone response to this event? Might the intersections between local performances in different national contexts, European Union funding for the project, Portuguese production and direction and an English text about Scotland reveal as much about the limitations as the strengths of such intercultural performances?

\section{Critical Interculturalism}

After a wave of critical interest in intercultural theory and practice during the '8os and ' 90 , there was something of a critical backlash against the term around the turn of the century. Theorist and practitioner Richard Schechner had revolutionized the field of performance studies by arguing for the importance of the intercultural over the international as a way of emphasizing exchanges between and within cultures rather than between nation states. This intercultural turn also militated against an exclusively

The Angolan Ministry of Culture alleges it was because of the poor conditions of the space." The practitioner José Mena Abrantes in Rede Angola (24 May, 2014) preferred to concentrate on the consequences of such a decision in a country with few permanent theatrical structures.

${ }^{3}$ Current members of the Comunidade de Países de Língua Portuguesa (CPLP), the Community of Portuguese-speaking nations, include Portugal, Mozambique, East Timor, S. Tomé and Principe, Angola, Cape Verde, Guinea-Bissau and, more recently and more controversially given its human rights record, Equatorial Guinea. 
Western, textual approach to questions of performance. However, Schechner's notion of "cultures of choice," with artists as "bricoleurs" who learnt from and used different performance traditions in their work brought criticism of an "excessive optimism" which ignored the fact that "economic and political conditions probably play a rather more devious and destructive role" than this notion of intercultural exchange suggested (in Pavis 1996:41). ${ }^{4}$ This intense polemic around the intercultural has more recently given way to a more measured assessment of its possibilities. Writing in 2008, Marvin Carlson notes that the intercultural constituted "a kind of bridge between earlier cultural studies and subsequent postcolonial work" (2008:132), a formulation which nevertheless suggests that the critical utility of the term had been provisional. For Patrice Pavis (2010:5), in a 2010 retrospective on "Intercultural Theatre today," the events of 1989 and 9/11 constituted something of a breaking point for interculturalism, after which it tended to be treated either with suspicion or a lack of interest. Pavis goes on to speculate that:

[t]his might be a sign that the metaphor of the exchange between cultures, between past and present, no longer functions very well and that one should at least reconsider its theory. The theory and practice of intercultural theatre of the eighties seem to be left behind by current theatre and performance. As if it could no longer be thought of in terms of national or cultural identity. (2010:5; my emphasis)

Pavis' accurate assessment of an interculturalism "caught between asserting universals and unchanging cultural difference" (2010:7) and increasingly irrelevant to a postnational order, suggests that the problem of the first wave of interculturalism lay in its tendency to cast national and cultural identity as fixed, immutable entities and thus to cast interculturalism as the impossible transcendence of such differences. In his attempt to rethink intercultural practice and

\footnotetext{
${ }^{4}$ An important aspect of Schechner's work on interculturalism that was often forgotten in this polemic was his emphasis on exchanges between practitioners as always being "modern to modern" (cit. in Pavis 1996:47). In other words, unlike Barba and Grotowski, Schechner was not attempting to work with notions of culturally pure indigenous performance traditions, but rather with contemporary international practitioners who referenced both indigenous and contemporary performance tendencies in their work. It was rather Peter Brook's Mahabharata (1985) and the criticism it provoked in Indian practitioners and theorists like Rustom Barucha that brought to a head this polemic around interculturalism.
} 
theory, Pavis makes two interesting observations, almost in passing. Firstly, he points to the fact that the new suspicion among critics surrounding the notion of interculturalism was rarely shared by performers, who tended to have a more positive, pragmatic view of the value of intercultural exchange. Secondly, Pavis suggests that the intercultural might usefully be seen as a variant of the interartistic, as "a form of interdisciplinarity, a crossing, a confrontation and an addition of arts, of techniques, of acting modes?" (2010:14). While such a view shies away from key questions of political (in)equality and geo-political location within both the interartistic and the intercultural, it does usefully point to the ways in which for practitioners, working with performers from other national contexts has often been something of a natural development of their existing intermedial work, rather than being qualitatively different from it. However, a focus on the potential of the intercultural should necessarily be balanced with critical attention to the conditions in which such intercultural exchanges take place. Jacqueline Lo and Helen Gilbert argue that one way to put into practice such a critical interculturalism would be to "explore the rhizomatic potential of interculturalism - its ability to make multiple connections and disconnections between cultural spaces - and to create representations that are unbounded and open, and potentially resistant to imperialist forms of closure" (2002:47). The challenge to formulate a new interculturalism is also taken up by Ric Knowles who argues that such a project "involves collaborations and solidarities across real and respected material differences within local, urban, national, and global intercultural performance ecologies" (2010:59). Within a context where the performances of The Prayers of Mansata brought together two former competing colonial powers (England and Portugal) and was funded by one supranational organization (The European Union) to travel within another supra-national context (Portuguese-speaking countries and Spain) with actors and actresses from a variety of national and cultural backgrounds, a focus on what Ania Loomba (2008:122) has referred to as the "multiple and shifting meanings" of the local, the national and the global suggests how the narrower focus on national and cultural identity in the first wave of intercultural theory might productively give way to more complex readings of the intercultural in contemporary post-colonial performances of Shakespeare. ${ }^{5}$

${ }^{5}$ An excellent example of just such a complex reading within Shakespearean 


\section{The Prayers of Mansata and Macbeth}

The Prayers of Mansata was Abdulai Sila's first play and the first published play in Guinea-Bissau, although such an affirmation obscures the long and rich history of performance in the country which has been based more on music, dance and physical humour than on written theatrical texts. Sila's play retains a clear intertextual relationship with Shakespeare's Macbeth, indicating the key role of Shakespeare as a marker for the coming of age of national drama. As Helen Gilbert and Joanne Tompkins point out:

the ideological weight of Shakespeare's legacy is nowhere felt more strongly than in the theatre, where his work is still widely seen as the measure of all dramatic art, the ultimate test for the would-be actor or director, the mark of audience sophistication and the uncontested sign of "Culture" itself. (1996:20)

Nevertheless, Sila's adaptation interrogates the inevitability of this encounter with Shakespeare and the ideological premises that sustain it. On the one hand, the Shakespeare play functions as a measure of the maturity of the national drama, giving credibility to the play as a product on the international theatrical market. On the other, the fact that Macbeth is a useful but by no means essential reference in understanding the play compared with local knowledge of mechanisms of power undermines claims of its geographical and historical universality. The references to Macbeth enable a writer within a still volatile political regime to intervene in contemporary questions of power without the direct retribution that might accompany an original play on the same themes. Yet, if Macbeth lends its status and authority to a contemporary critique of power in Guinea-Bissau, The Prayers of Mansata also points to the limitations of the Shakespeare play in effecting such a critique. It illustrates in particular the inadequacy of Macbeth's rather simplistic moral and political framework in analysing contemporary configurations of post-colonial power. In The Prayers of Mansata, power is portrayed as circular rather than linear, without any secular or spiritual saviour to

performance studies is W.B. Worthen's 2003 analysis of the Brazilian company Grupo Galpão's Romeu e Julieta at the Globe Theatre in London in his chapter "Shakespearean Geographies" (157-68). Through the simple move of employing a Portuguese translator, Worthen avoids the emphasis on immediacy and physicality that characterized most reviews of the performance to show instead the highly contemporary and professional contexts for this particular performance. 
save the nation from itself as Macduff does in Macbeth. Similarly, gender relations between men and women are not naturalized in The Prayers of Mansata in order to demonize the ambitious, childless woman as they are in Macbeth, but rely clearly on political and economic power relationships geared towards financial rewards. As such, a relationship of intertextual friction is maintained between the Shakespeare play and Sila's adaptation.

Like other adaptations of Macbeth to African contexts, ${ }^{6}$ the focus of The Prayers of Mansata is on internal struggles for power within the ruling elite and on the coups and counter-coups which have blighted the history of Guinea-Bissau since it proclaimed its independence from Portugal in $1973 .{ }^{7}$ As in the Shakespeare play, there is a strong emphasis on the connection between spiritual and political power. The first two scenes of Mansata introduce the figure of Kemeburema, who is approached by three men and then three women who treat him as their leader despite his protestations of ignorance. The doubling of the number three in both male and female form recalls the witches in Macbeth, yet the focus in the adaptation is more on the ways in which the never-ending cycle of violence and bloodshed leads the population to seek spiritual leaders who stand outside this cycle. The two figures with political power in the play, Mwankeh (the Duncan figure) and Amambarka (the Macbeth figure) consult a group of three spiritual councillors in order to convince themselves and others of their legitimacy to rule, but the opportunistic impetus of such consultations is made clear when one of Amambarka's political councillors improvises a connection to a powerful woman

\footnotetext{
${ }^{6}$ Examples of other African Macbeths would include Welcome Msomi's play uMabatha (1970), which places the conflict in a nineteenth-century, South African Zulu context and the film Makibefo (1999), directed by Alexander Abela, an adaptation of Macbeth to the context of Madagascar. While both these cultural products have used the play to make significant social, political and aesthetic comments with regard to the contexts in which they are located, their reception has often been conditioned by a tendency towards conceiving them as "a site of exotic speculation" (Hinz 2007). Some criticism of $u$ Mabatha has placed discussion of the play more productively within an analysis of intersections between the local and the global (Orkin 2005) or the place of Shakespeare within post-colonial educational regimes (Distiller 2004). Similarly, useful discussions of Makebefo have focused on the politics of the aural and visual (Hinz 2007) or on redefining notions of the auteur in post-colonial film (Burnett 2012).

${ }^{7}$ Guiné-Bissau proclaimed its independence from Portugal in 1973, but it was only after the 1974 Portuguese Revolution that the country's independence was recognized by Portugal.
} 
named Mansata in order to save his life. The ways in which spiritual and political powers reinforce each other is brought home near the end of the play as Amambarka is murdered for a piece of paper that supposedly contains one of Mansata's prayers. In a bloody closing of the circle, a dying Amambarka uses the last of his strength to murder the man who has murdered him. His final words, and the final words of the play are "zero," a stark indictment of the concrete results of such internecine struggles for the people of Guinea-Bissau.

The emphasis on the symbolism of the number three also inflects the decision to have three wives for Amambarka: Annura, Djuku and Nghalula. On the one hand, this emphasizes the power of the Lady Macbeth figure over Macbeth as each of Amambarka's wives persuades him to "be a real man" $(59)^{8}$ and claim back the power he has lost within the ruling elite. On the other, it reflects the continued importance of polygamy in contemporary Guinea-Bissau. The multiplication of the number of wives thus keys into questions of contemporary gender politics, for all three wives see Amambarka as a meal ticket rather than a romantic partner and their financial dependence on him leads to frustration, bitterness and emotional distance at his inability to maintain them. While the wives seem at first glance to control Amambarka, their disobedience is shown to have serious consequences as they are reduced verbally to the status of whores and, in the case of Nghalula, physically attacked.

Violence and the constant threat of betrayal accompany the struggles for power throughout the play. Amambarka's conspiracy against Mwankeh unites Mwankeh's own councillors who then turn on Amambarka to improve their own chances of power. Both leaders consider betrayal the worst possible outcome and Mwankeh reveals in private that the possibility of betrayal haunts him day and night:

I haven't slept peacefully in days, there's so much hatred in the air [...] Sometimes I wake up in the middle of the night and I feel blood, heavy blood, running down my nose, blocking my nostrils and my throat, stopping me breathing [...] When I look around, there's only one thing I see: traitors! This is a nation of traitors! I'm not afraid, I've never have been afraid of anyone or anything, but I can't stand betrayal. (42)

\footnotetext{
${ }^{8}$ All excerpts from the play are my own translations.
} 
This fear of betrayal also inflects their paranoid attitude to opposition, whether in the form of political opposition within the country or criticism on the Internet from those in exile, a division which the Internet itself is shown to complicate. However, both Mwankeh and Amambarka continue to betray and to be betrayed despite their attempts to secure the loyalty of the councillors through ritualized oaths of allegiance. In two haunting scenes of the play, the ghosts of those Amambarka has tortured in the past mix with those who have taunted him with his powerlessness in the present. The tortured remind him of the bloody methods he has used against supposed allies and former friends, including apoloh, a practice whereby the victim is suspended by their feet while their head is periodically lowered into a tank of water. The way in which these ghosts visit Amambarka recalls the virtual appearance of a bloody Banquo in Macbeth but apart from these nightmarish sequences, there is no character in The Prayers of Mansata who appears able to break the cycle of betrayal and counter-betrayal. Such a cycle is presented as an inevitable corollary of structures of political power that rely on the oppression of the majority of the population at the expense of a favoured few.

As Russell G. Hamilton (2011:9-10) points out in his preface to the play, the action of the play takes place in a post-colonial setting far removed from Shakespeare's Scotland, although no location is referred to directly within the play. Nevertheless, three factors identified by Joshua Forrest (2002) as continuing concerns in postcolonial Guinea-Bissau are present throughout the play, namely uneven economic development, the continuation of pre-colonial and colonial forms of authority and political personalism. As the councillors dispute financial benefits, for instance, the spiritual councillors remind Mwankeh that the population lack schools, while the influence of the spiritual councillors on Mwankeh and Amambarka points to the continued significance of locally-based spiritual authority. Both Mwankeh and Amambarka consider the cult of personality essential to the maintenance of power and confuse their own rise and fall with that of the nation. However, this postcolonial setting does not mean the legacy of colonialism is entirely erased. Amambarka invokes comparisons with "the whites" in a political speech when he wants to encourage a sense of injustice in his audience in relation to those who continue to have power and might "enslave us once again"(120). There are frequent references to 
"our friends abroad," (35) neo-colonialists who continue to interfere directly or indirectly in questions of economics and politics. As such, despite Ania Loomba's warning (2008:122) that "it sometimes seems that a neo-imperial Shakespeare and a postcolonial one can be collapsed into a single highly marketable Shakespeare who simultaneously represents once-colonized and once-colonizing cultures," the layering of the precolonial, the colonial and the postcolonial in The Prayers of Mansata avoids such a collapsing of different historical moments. It locates the play specifically in contemporary Guinea-Bissau but also leaves it open to resistant readings in other post-colonial contexts. This feature of the Shakespearean adaptation was crucial in constructing a platform for an intercultural performance.

\section{Dramaturgical structure and performance time}

The tensions of what is already an interculturally-positioned text can either be downplayed or foregrounded in performance. In this sense, the choice of performers from a variety of national contexts is itself an indication that the director (António Augusto Barros) and the creative team aimed to give prominence to the intercultural features of the play. ${ }^{9}$ In terms of the type of questions which might help to structure critical analysis of such intercultural performances, Julie Holledge and Joanne Tompkins' call for more critical attention to questions of "intercultural performance time, dramaturgical structures, emotional expression and audience-stage relations" (2000:39) resonates productively with the performances of The Prayers of Mansata where the dramaturgical structure combined moments of linearity and non-linearity as well as expansion and contraction and where oral and written languages intersected with and interrogated each other. Additionally, the questions formulated by Jacqueline Lo and Helen Gilbert (2002:42), which include "whose language is used during the rehearsal process? Where does the

\footnotetext{
${ }^{9}$ Cena Lusófona first asked Abduali Sila to write a play for their collection of plays by lusophone writers and then chose the text for this particular intercultural project. There were two performative precedents for the intercultural performance. The first was Makbunhe, which Cena Lusófona brought to Coimbra when it was Capital of Culture in 2003. Then, in 2007, Namanha Makbunhe, which involved several of the practitioners who would later be involved in The Prayers of Mansata, was performed in Lisbon.
} 
project take place? How is power inscribed on and negotiated through the body? And how do these bodies encode difference?," raise significant political questions about the premises of specific intercultural performances. Both sets of questions aid analysis of the ways in which "Shakespeare" and "intercultural performance" are constructed and connected at particular moments in time and in particular locations.

In terms of dramaturgical structure, The Prayers of Mansata is not simply a linear narrative. Although, like Macbeth, the play follows Amambarka's rise and eventual fall from power, the play's structure is more complex than this main narrative suggests and complements the play's thematic focus on power as cyclical. The first act, for instance, where three talibés and three katanderas $^{10}$ predict a bright future for Kememburema creates an interest in the character which suggests he will come to play an important role in the play. However, although the fact that Amambarka accidentally knocks over one of the Katanderas' pots is made significant later on in the play, Kememburema himself disappears, to be replaced by the three spiritual councillors and the mythical Mansata. Similarly, although the title of the play carries her name, there is no Mansata character as such. An implicit contrast is sustained between those who seize power for themselves, like Mwankeh and Amambarka, and those like Kemeburema and Mansata to whom power is attributed by the people, but there is a sense that the characters themselves are functionally interchangeable within the play's dramaturgical structure.

In the rest of the play, there are several scenes that rely on the notion of repetition with a difference. Mwankeh and Amambarka's separate encounters with the three spiritual councillors in Act Two and Act Six, for instance, reveal the same desire to reinforce their political power with spiritual legitimacy. The scene in Act Two where the councillors swear loyalty to Mwankeh is replayed in a later scene in Act Four where these same councillors swear loyalty to Amambarka. Similarly, while the three scenes with Amambarka's wives might well have been condensed into one scene where Amambarka is castigated for his lack of manhood, each of these

\footnotetext{
${ }^{10}$ Katanderas are young women who serve in places of religious worship while talbés are young male Koranic disciples.
} 
separate scenes adds a slightly new angle to this taunt. Annura's monologue first sets out the case against Amambarka. Djuku's scene provides a background for the frustration from the perspective of an educated, more liberated woman and Nghalula embodies the notion of opposition to reinforce the intersections between violence against the wives and violence against the political opposition. In this sense, the repetitions function to provide comparison and contrast or work to strengthen particular themes of the play without creating a sense of linear development.

As is the case with the wives, there are several scenes where the events of the previous scene are carried on into a new scene to provide a slightly different perspective on the events or to develop a minor narrative within the main narrative. Mwankeh's public dealings with his councillors stretch over two scenes in Act Two and contrast with his semi-private admission of fear to the spiritual councillors which extends over the next two scenes. Councillor Nkungha's attempts to save his life cover three entire scenes in Act Five. In the first, he distances himself from Amambarka in order to prove his loyalty to Mwankeh, while in the second, he distances himself from Mwankeh and hails Amambarka's victory as "a work of God, a miracle" (97) before attempting to save his life by proving how much he knows about Mansata. This story of Mansata continues in the next scene where Nkungha provides Amambarka with the information he wants to hear. As in this case, a long scene is often followed by a short scene dealing with the same material or a short scene introduces a theme or story that is developed in subsequent scenes, alternating notions of expansion and contraction within the dramaturgical structure.

These repetitions and continuations of scenes into each other create a dramaturgical structure based on the accumulation of similarities and differences that resonate productively with each other. This structure is reminiscent of the work in the performance workshop in Guinea-Bissau during the previous year around the theme of storytelling, where it became clear that rather than telling stories in a sequential fashion that pointed to markers such as "and then," "next" and so on, the participants used the accumulation of detail to create an open, flexible structure for their storytelling. Sila's text is constructed very much on the same premises, with characters appearing and disappearing and entrances, exits and events not 
confined within act and scene divisions. As such, Sila's text subverts the centrality of sequential narrative in a way that also questions narratives of history as objective storytelling. As Ashcroft, Griffiths \& Tiffin argue, the post-colonial task:

is not simply to contest the message of history, which has so often relegated individual post-colonial societies to footnotes to the march of progress, but also to engage the medium of narrativity itself, to re-inscribe the "rhetoric," the heterogeneity of historical representation as (Hayden) White describes it. (1995:356; my emphasis)

In its combination of the linear and non-linear, of expansion and contraction, the dramaturgical structure of The Prayers of Mansata thus challenges colonial historical narratives through its interrogation of the mechanisms of (his)torytelling and, arguably, comes closer to Macbeth's own highly episodic structure.

Heterogeneity also characterizes the inclusion of written and oral languages in the play. In particular, several items of vocabulary specific to Guinea-Bissau are included within the Portuguese text. These range from the responsibilities given to the Ministers (BagarBagar, Kibir-Kabar, Meker-Meker) ${ }^{11}$ to Act headings such as Djapuf Power, ${ }^{12}$ to persistent references to djanfa (treason) and the linkage of the Internet to an yran (god or sacred spirit). Moreover, the play also includes some words invented by Sila himself such as Suprematura (the office of the Supreme Chief) while the mystical inscription at the beginning of the published play, "Ko nafata kon fow lorrai" is not explained either by the characters or the author in the glossary at the end of the play. Such linguistic markers were received with recognition and pleasure by audiences in Bissau and also worked to undermine the authority of standard Portuguese by placing local, oral-based languages on an equal footing with written Portuguese and its traces of the English Shakespearean text. As Gilbert and Tompkins (1996:167-68) correctly point out, the inclusion of oral cultures not only gives a particular sound and rhythm to a play, but also emphasizes the site from which language is spoken. They add that "[t]he strategic use of languages in post-colonial plays helps to reinvest colonized peoples and their characteristic systems of

\footnotetext{
${ }^{11}$ Respectively, chaos, anarchy and intrigue.

${ }^{12}$ Djapuf is a variety of crab that feeds on detritus. As such, the title means something like dirty or filthy power.
} 
communication with a sense of power and an active place on the stage," a sense of empowerment that applied both to performers and to audiences of The Prayers of Mansata.

Each of the performances of The Prayers of Mansata lasted two and a half hours, with one interval. Nevertheless, within this external performance time, distinct rhythms co-existed and the development of the action was complemented by moments of song, dance or visual tableaux that punctuated the dramatic narrative. The tableau that opened and closed the performances, for instance (Fig. 1) created a powerful, extended, visual images of the effects of power on the population. To begin with, the lights went up to reveal the performers huddled in and around the wheelbarrows that are used to transport all kinds of produce around Bissau to the sound of the kora, a 21-string lute-bridge-harp used extensively in West Africa. The corporeal positioning of the performers made it unclear whether they were asleep or dead, whether they were handling the wheelbarrows or were instead the products to be transported.

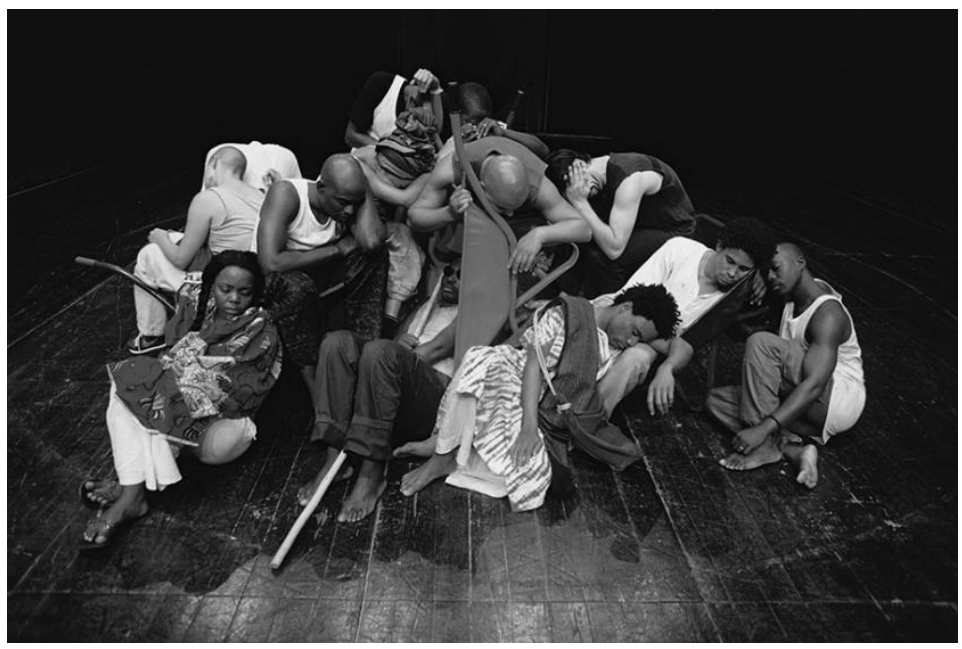

Fig. 1. Photograph by Augusto Baptista. Image courtesy of Cena Lusófona.

At this stage, however, the performers rose to their feet and the performance began with a vibrant street scene where the performers exchanged greetings and recriminations while going about their daily business. However, when the same tableau was (re)cited at the end of the performance, after the deaths of all the main characters, 
the bodies huddled around the wheelbarrows took on a more sinister meaning, for they seemed more obviously dead, the disposable human cargo of factional struggles for power among the political elite.

The Prayers of Mansata worked with performers from a variety of theatrical backgrounds. Some came from a primarily text-based form of theatre, while others came from backgrounds in physical theatre, comedy or song and dance. In this particular case, it was a Portuguese text-based tradition that predominated in rehearsals and performance, essentially because it was based on a dramatic text in Portuguese and Portuguese was also the language of rehearsals and performance. However, the intercultural positioning of the initiative was complemented by a cross-fertilization of performance forms and theatrical experiences among performers. Indeed, the notion of sharing performance knowledge was built into the rehearsal process. Performers taught each other songs, dances or body movements and experimented with forms of speaking the text in peer-oriented forms of theatrical learning. A professional capoeira teacher (Professor Flajla) was also engaged during the rehearsal period in S. Tomé to work with the cast along with a choreographer (Zebrinha) and musical director (Jarbas Bittencourt). As the performers had a relatively long rehearsal period together in different national contexts and toured together during the performances, formal and informal learning continued to be part of the performance process. A haunting Angolan song dealing with the losses of war, for instance, was taught to other practitioners during rehearsals by an Angolan actress (Marleny Musa) and in the performances, her rendition of the song was taken up as well by others in the cast. In a different form of theatrical crossing, the physical comedy skills of the performer playing Nkungha (Trindade Gomes da Costa), the councillor responsible for nhengher-nhengher (conspiracy) were complemented by his skill in speaking a text he had worked on extensively in rehearsal, for Portuguese was not his first language. In a comic setpiece, Nkungha first tried to convince Mwankeh that he had been forced into the conspiracy against him by the devilish Amambarka. However, at the exact moment in which Nkungha was demonstrating physically the compromising position into which Amambarka had forced him, Amambarka himself burst in with his co-conspirators and murdered Mwankeh. This turn of events forced Ngungha into a rapid volte-face that focused the verbal and physical 
comic skills of the performer and turned two long scenes of the play into virtuoso, audience-directed moments of performance. As in this instance, several performers relished the opportunity to step in and out of their roles in order to encourage greater interaction with the audience, temporarily creating moments that deferred the development of the dramatic narrative. Moreover, the combination of different stage languages in performance deconstructed the notion of the primacy of the dramatic text as well as the primacy of a textbased theatrical tradition among performers of Shakespeare.

\section{Corporeal stereotypes and collective embodiment}

For Lo and Gilbert (2002:47), the central question of intercultural performance remains "[h]ow to avoid essentialist constructions of race and gender while still accounting for the irreducible specificity of certain bodies and body behaviours." A very simple way of highlighting the specific location of the performing body without reinforcing essentialism is through the use of doubling, which can reveal "the gaps between the performing body and the performing subject," and give "voice to many and ultimate authority to none" (Gilbert \& Tompkins 1996:34, 233). In performances of The Prayers of Mansata, only the actor playing Amambarka (Rogério Boane) played just one role. All other performers played at least two different roles. Contrasting with their early appearances as the young Katanderas, for example, the appearance of the same three actresses later as Amambarka's wives left unsettled questions of their age and status. Actors who played spiritual councillors reappeared as their more temporal equivalents, playing against any essentialist division between the political and the spiritual, as well as against moral binaries of good and bad and their location in specific performing bodies. Playing such different roles also required different skills from the actors at different moments of the performance that militated against the fixation of national and cultural stereotypes in relation to performance methods and techniques. This was particularly true of the actor playing Amambarka, an actor born in Mozambique but whose career has developed mainly in Portugal. His was a particularly complex part to play, for the role required mercurial changes of mood as well as intense verbal and physical energy. Towards the end of the Bissau performances, the responses of the audience indicated that they were simultaneously repelled by 
and attracted to the figure of Amambarka in a somewhat paradoxical gesture of appreciation for Boane's performance. ${ }^{13}$ This suggested that the audience also moved between moments of identification of the performer with the role and moments that clearly distinguished the two.

A crucial test for intercultural performance is the extent to which group scenes both foreground differences between the actors yet also create a sense of a provisionally homogenous group. In The Prayers of Mansata, this was particularly important for the scenes involving the councillors, both spiritual and secular. In the first scene with Mwankeh's inner circle, the group was defined through the intersection between the physical and the textual. The fact that these councillors were responsible for matters of bagar-bagar (chaos), tchumul-tchamul (disorder) and mukur-mukur (secrecy) and that the matter of state to be discussed was the struggle of one of the First Ladies to travel with "a better class of people" (28) in a private jet, framed this first encounter as satirical farce, while the fact that each of the councillors kicked a file representing responsibility for dealing with the matter along the floor to the councillor sitting next to him indicated through a deft physical movement the reluctance to take responsibility of those supposedly in charge of national affairs. Common gestures within the group such as brushing non-existent dust off the shoulders or swivelling the head around abruptly to focus the gaze on the next person in the line were coordinated by all performers and, in a majestic final collective movement away from responsibility, all the councillors turned to one side to reveal bare legs and thighs that counterpointed their otherwise fashionable suits. In this way, despite the different physical appearances, forms of Portuguese and theatrical backgrounds, a coherent image of the chaos of authority was created for the performances.

For the spiritual councillors, proxemics and vocal inflection were important in creating an image of authority as a group. While in

\footnotetext{
${ }^{13}$ The Bissau audience actually cheered Amambarka when he appeared in a suit as the new Supreme Chief, though they had mocked his earlier claims to be interested in the social and economic development of the country, indicating that the response was an acknowledgment of the skill of the performer and their presentation of the material rather than agreement with the political content of the speech. Content and presentation did sometimes coincide, as when Amambarka gave his speech on equality between black and white to applause from the audience.
} 
their first encounter with Mwankeh, the three performers were seated on a mat which Mwankeh was then invited to share, the versatility of the simple stage set enabled struggles for power to be conveyed through vertical contrasts in height (Fig. 2). As Amambarka became increasingly desperate to discover the

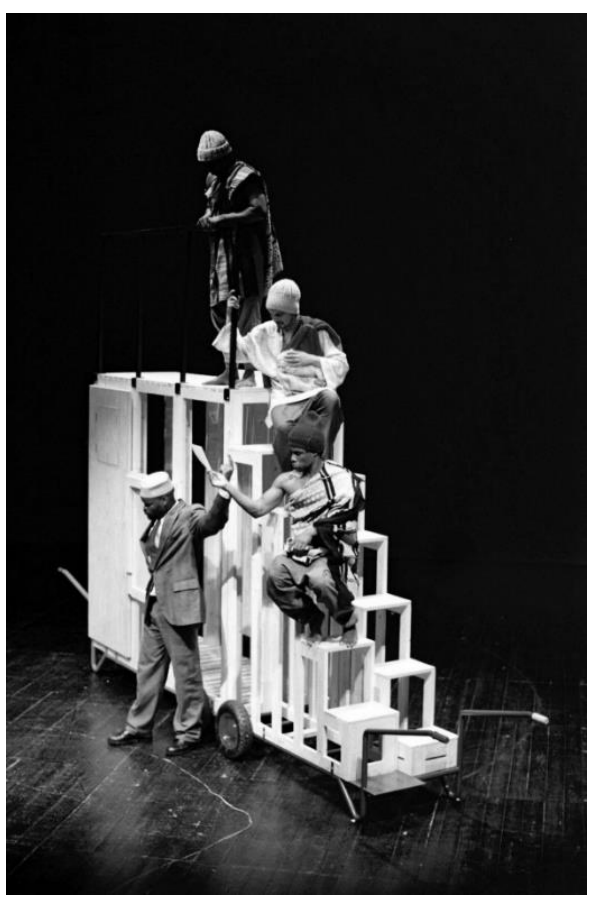
whereabouts of Mansata, his loss of authority was made clear by the fact that while he remained on the ground, the three spiritual councillors spoke to him from above on a platform. The Guinean, Portuguese and Brazilian actors (Jorge Biague, Igor Lebreaud and Ridson Reis) who played the councillors maintained different forms of intonation and physicality, but a more sober tone of voice and a slower rhythm in speaking the lines created an effective image of the greater power of these councillors over the politicians.

Fig. 2. Photograph by Augusto Baptista. Image courtesy of Cena Lusófona.

A scene that involved all performers was the harrowing scene where past and present ghosts visited Amambarka. While Amambarka tossed uneasily in the middle of a bed on a sparsely-lit stage, he was visited by ghosts with bloody hands or misshapen bodies. Their bodily positions ranged from the totally upright to the totally curved over to those crawling along the floor in a scene that resembled an image of hell by Hieronymous Bosch. The ghostly return of Amambarka's victims and their movements around the bed as they spoke, combined with the minimal lighting, created a particularly powerful visual image of the violence associated with personal and political power. As Gilbert \& Tompkins (1996:221) 
note, often "the personal site of the body becomes a sign of the political fortunes of the collective culture," and in this particular instance, the fact that all performers were involved in this scene with their own particular body languages created a dramatic and social sense of a post-colonial collective traumatized both by its ghosts and its hallucinatory present. ${ }^{14}$

\section{Post-colonial trauma and intercultural farce}

Although such a connection was not made explicit, there was an implicit assumption in these performances of The Prayers of Mansata that intercultural performance might represent a means of staging the post-colonial trauma of Portuguese-speaking nations. Such trauma results from the frustration of expectations of change after independence and recognition of the non-progressive roles of the former colonizing power, those currently in power and their neocolonial allies. Yet to what extent can intercultural performance effectively stage such trauma? This particular performance project aimed to balance the specificity of a play from one post-colonial context with a sense that the concerns raised by the play might resonate in other Portuguese-speaking contexts. However, the presence of Brazilian practitioners in particular complicated such a project, for Brazil has a much longer history of independence from the colonizing power than the African nations involved in the project and a substantially different geo-political role from both Portugal and the African nations in the present. Even within the African nations, Angola is fast becoming a major economic and political force in a way that is very different from Guinea-Bissau and S. Tomé and Príncipe. As such, the geo-political axis of centre and periphery within the Lusophone nations is undergoing major changes and such transformations inevitably inflect intercultural performance. In this particular case, this can be seen in the fact that the text for the project combined two authors, one very much connected with the beginnings of colonialism, the other reflecting on its legacy, while the performances were funded by the European Union to travel within a circuit far removed from its usual geographical remit.

\footnotetext{
${ }^{14} \mathrm{~A}$ sense that such scenes of torture can resonate beyond national borders was made clear in a post-production conversation, where an Argentinian member of the audience admitted she had been particularly affected by this scene.
} 
Within this context, it might be useful to reflect on the performances' use of farce, both physical and verbal, as a dominant performance form. To adopt the Marxist adage that history repeats itself, first as tragedy, then as farce, there is a sense in these performances that farce as a genre encompasses anger both at the tragedy of colonialism and its unwelcome repetition as farce under post-colonialism. The adoption of farce in performance does not minimize the violence and abuses of the colonial or the post-colonial period. Instead, it places them in a framework where they are doubly indicted; firstly, because they do not deal with the historical ravages of colonialism and secondly, because they do not provide the much-desired alternative to it. Farce might be seen as an easy way to work with very different performers and to appeal to widely diverse audiences, but the pleasures of easy recognition should also be balanced against the ability of laughter to ridicule those at whom such laughter is directed. Indeed, it was precisely this staging of power as farce that fuelled a wider political farce with the cancellation of the performances in Luanda. While the Angolan government might have been comfortable with the circulation of the printed text in the country, convinced that its circulation would remain within an educated elite, it seems to have been the performances of the play which aroused the hostility of the Angolan authorities. This suggests that such intercultural initiatives, whatever their limitations, can represent a potent political and cultural intervention in their ability to ridicule those in power and thus demand political transformation. The Prayers of Mansata focused some of the contemporary tensions within the notion of a Lusophone community of nations, both in terms of pointing to its precarious balance of power and in terms of highlighting its often unacknowledged divisions, while also pointing through performance to possible countercultural constructions of the Lusophone.

The performances of The Prayers of Mansata also raise an important question for Shakespearean performance critics. Invariably, performance criticism is based on one performance in one national context, yet as this series of performances makes clear, such analysis does little justice to the different circumstances of production and reception that characterized this intercultural staging of an intercultural play. This suggests that it may be necessary to think differently about how to analyse such 
intercultural performances of Shakespeare, either by bringing together a group of performance critics in different national contexts who could compare their different impressions or through individual performance critics combining their perspectives with practitioners who have been involved in the performances as a whole. In such a way, a richer and more productive analysis of intercultural performances of Shakespeare might be achieved through collaboration, for it might more accurately capture the "rhizomatic potential" of intercultural performances such as The Prayers of Mansata to reflect on and destabilize contemporary configurations of post-colonial power.

\section{References}

Abela, Alexander dir. 1999. Makibefo. Film.

Abrantes, José Mena 2014. "Mal-estar Teatral." Rede Angola 24 May 2014 <url: http://www.redeangola.info/opiniao/mal-estar-teatral/>. Last accessed 06/02/2015.

Ashcroft, Bill, Griffiths, Gareth, \& Tiffin, Helen 1995. The Post-colonial Studies Reader. London: Routledge.

Barros, António Augusto dir. 2013-2014. As Orações de Mansata. Performance. Scenography: Joaõ Mendes Ribeiro/Luísa Bebiano: Lighting design:Fernando Conceição. Kora: Braima Galissa. Vídeo: Andrzej Kowalski.

Bharucha, Rustom 1993. Theatre and the World: Performance and the Politics of Culture. London \& New York: Routledge.

Burnett, Mark Thornton 2012. Shakespeare and World Cinema. Cambridge: Cambridge University Press.

Carlson, Marvin 2008. "Intercultural theory, postcolonial theory, and semiotics: The road not (yet) taken." Semiotica 168/1-4: 129-42.

Distiller, Natasha 2004. "The Zulu Macbeth': The Value of an 'African Shakespeare'." Shakespeare Survey 57: 159-68.

Forrest, Joshua 2002. "Guinea Bissau." Patrick Chabal et al. A History of Postcolonial Lusophone Africa. Bloomington: Indiana University Press: 23663.

Gilbert, Helen, and Joanne Tompkins 1996. Post-colonial Drama: Theory, Practice, Politics. London-New York: Routledge.

Knowles, Ric 2010. Theatre and Interculturalism. Basingstoke \& New York: Palgrave MacMillan. 
Hamilton, Russell G. 2011. Prefácio. As Orações de Mansata. By Abdulai Sila. Coimbra: Cena Lusófona: 9-12.

Hinz, Philipp 2007. "Shakespearean Ventriloquisms: Sound, Sight, and Spectacular Exoticism in Makibefo." Shakespearean Soundscapes: Music Voices - Noises - Silence. Ausgabe 5: 43-50. <url: http://shakespearegesellschaft.de/uploads/media/WSO_5_2007.pdf $>$._LLast Accessed 20/01/2015.

Holledge, Julie and Joanne Tompkins 2000. Women's Intercultural Performance. London \& New York: Routledge.

Lo, Jacqueline and Helen Gilbert 2002. "Towards a Topography of CrossCultural Theatre Praxis." The Drama Review 46/3: 31-53.

Loomba, Ania 2008. "Shakespeare and the Possibilities of Postcolonial Performance." Eds. Barbara Hodgdon and W.B. Worthen. A Companion to Shakespeare and Performance. Malden, MA and Oxford: Wiley Blackwell: 121-37.

Msomi, Welcome 1970. "UMabatha." Eds. Daniel Fischlin and Mark Fortier 200o. Adaptations of Shakespeare: An Anthology of Plays from the 17th Century to the Present. London \& New York: Routledge: 164-87.

Orkin, Martin 2005. Local Shakespeares: Proximations and Power. New York: Routledge.

Pavis, Patrice 1996. "Interculturalism and the culture of choice: Richard Schechner interviewed by Patrice Pavis." Ed. Patrice Pavis. The Intercultural Performance Reader. London and New York: Routledge: 4150.

2010. "Intercultural theatre today." Forum Modernes Theater, Bd. 25/1: 5-15.

Rayner, Francesca 2014. The Prayers of Mansata. Unpublished translation.

Sila, Abdulai 2011. As Orações de Mansata. Coimbra: Cena Lusófona.

Siza, Rita 2014. "Co-produção teatral porutugesa cancelada horas antes da estreia dem Luanda." O Público 17 May 2014.

<url: http://www.publico.pt/culturaipsilon/noticia/coproducaoteatral-portuguesa-cancelada-horas-antes-da-estreia-em-luanda1636421>. Last accessed 06/02/2015.

Tomet, Willian 2014 "Cultura Censurada ou só Nepotismo?" Folha 824 May 2014 <url: https://pstage.files.wordpress.com/2014/07/2014-05-24folha-8-ao.pdf $>$. Last accessed 06/02/2015.

Worthen, W.B. 2003. Shakespeare and the Force of Modern Performance. Cambridge: Cambridge University Press. 
"Bloco Democrático contra a proibição da peça de teatro "Orações de Mansata" pelo Ministério da Cultura." Blog Oficial do Bloco Democrático em Luanda 16 May 2014.

<url: http://bdluanda.blogspot.com.es/2014/05/bloco-democraticocontra-proibicao-da.html>. Last accessed 06/02/2015.

"Ministra da Cultura censura peça de teatro que retrata a corrupção" Diario Angolano. 19 May 2014.

<url: http://www.diarioangolano.com/index.php/politica/167corrupcao/102...ministerio-da-cultura-censura-peca-de-teatro-queretrara-corrupcao $>$ Last accessed 06/02/2015. Note that this website may have geographical access restrictions.

How to cite this article:

Rayner, Francesca. "Adapting Macbeth in a Lusophone context: the challenges of intercultural performance." SEDERI 25 (2015): 129-151.

Author's contact: frayner@ilch.uminho.pt

Postal address: Centro Avançado de Formação Pós-Graduada - Universidade do

Minho - Rua de Vila Flor, 166 - 480o-437 Guimarães, Portugal

Submission: 17/11/2014

Acceptance: 14/01/2015 